\title{
Assessing the Effectiveness of Health Preparedness Capacity Building Intervention in Empowering the Urban Poor Community in Rodriguez, Rizal, Philippines
}

\section{Marlon Cadauan Mallillin III, RPh, MPHI 1,2, Mary Agnes Santos-Regal, MD, MPH, MSc}

\begin{abstract}
This study deals with the public health effects of a natural disaster and some public health principles that can be applied to disaster risk reduction and management, focusing on earthquake preparedness for Barangay San Jose - Rodriguez, Rizal, Philippines. The study showed that the urban poor community has a weak history of engagement, and it explores whether facilitated community interventions can empower and develop community preparedness. It followed a participatory approach involving community leaders and members. The study indicated that enhancing and modifying interventions that match community needs will develop community preparedness in the community, potentially increasing the chances of surviving an earthquake and minimizing its deleterious and damaging impact. Community preparedness will require continuous involvement and a cooperative approach to working with communities to support equal and harmonized development.
\end{abstract}

Marlon Cadauan Mallillin III

momallillin@ust.edu.ph

1. Faculty of Medicine and Surgery, University of Santo Tomas, 1008, Philippines

2. Faculty of Pharmacy, University of Santo Tomas, 1008, Philippines
Key words: Public health, disaster preparedness, community engagement, capacity building, risk reduction

\section{INTRODUCTION}

Disasterscause serious problemsthat demandahuman toll and are concerns of public health interventions. [1] Natural disasters such as earthquakes remain as one of the biggest challenges for developing countries like the Philippines.[2] The Philippines is one of the top 10 countries experiencing the highest number of disaster events due to its vulnerability to disasters, mainly geophysical and its recognizable tectonic activities. [3]

According to the Metropolitan Manila Earthquake Impact Reduction Study (MMEIRS), [4] the probability of a 7.2 magnitude earthquake, also known as "The Big One," is significant. It is a setting from the West Valley Fault that will cause severe destruction of properties and infrastructure and result in thousands of injuries and lives lost.

Republic Act No. 10121,[5] the "Philippine Disaster Risk Reduction and Management Act of 2010", was enacted to strengthen the Philippine disaster risk reduction system. This republic act institutionalizes the policies and programs on disaster risk reduction from national to local levels in building a disaster resilient country and communities. 
Therefore, developing an appropriate disaster risk reduction program can be achieved through lessening disaster risks through organized community efforts to evaluate and mitigate the significant factors of disasters by reducing exposure to risks and hazards, lessening vulnerability, and augmenting preparedness for disaster events. [6-8]

There should be a promotion of capacity building for community disaster risk reduction, particularly at the local level to increase skills and knowledge and improve local tools and equipment. Active participation of the community at risk should be practiced reducing their vulnerabilities while increasing their capacities. $[9,10]$

Geographically, Barangay San Jose - Rodriguez, Rizal is traversed by the West Valley Fault System that can generate a magnitude 7.2 earthquake. Phase 1K Kasiglahan Village is located in Barangay San Jose - Rodriguez, Rizal. Kasiglahan Village is an urban poor community, resettlement area project of the Philippine government's National Housing Authority. Kasiglahan Village is not appropriate for a socialized housing project because of its known high vulnerability to flooding and earthquake.

With the earlier mentioned information, the researcher aims to investigate the effectiveness of capacity building intervention on disaster risk reduction and management of Barangay San Jose Rodriguez, Rizal on earthquake preparedness.

\section{METHODOLOGY}

Based on the results of training needs assessment (TNA) with members of the Barangay Disaster Risk Reduction and Management Office (BDRRMO) and community leaders along with collection and review of secondary data, observation, and community assessment, earthquake contingency emergency planning is lacking in the Barangay Disaster Risk Reduction Plan of Barangay San Jose - Rodriguez, Rizal.

\section{Conceptual Framework}

Figure 1 shows the processes of implementing Community-Based Disaster Risk Reduction and Management (CBDRRM). The community's selection is the first step wherein a history of the disaster, community vulnerability, and potential to become a disaster distribution point must be considered. The next step is building rapport and understanding the community through community immersion like living in the community and merging in their daily activities. They were followed by doing a disaster risk assessment, such as hazard, vulnerability, and capacity assessments. The fourth step is the disaster risk management planning. In this step, the creation of contingency plans and policies as well as advocacy are realized.

\section{Conceptual Framework}

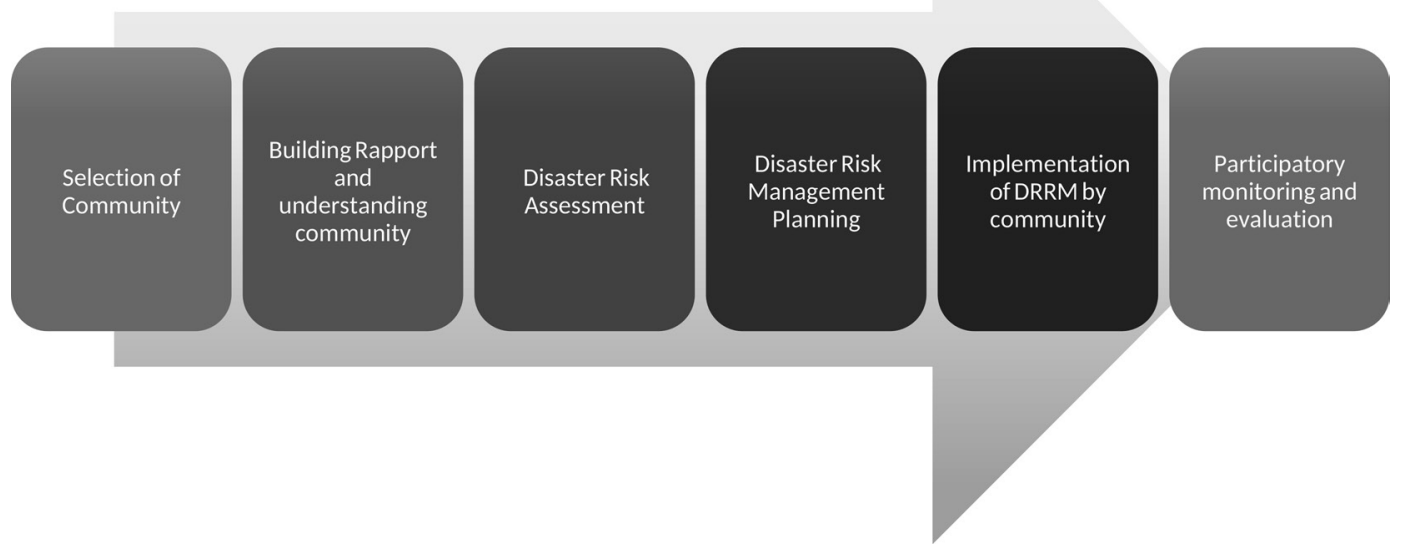

Figure 1. Conceptual Framework of Community-based Disaster Risk Reduction and Management 
The fifth step is the implementation, prepared, and arranged upon activities that are achieved and fulfilled through a series of activities by the community. Lastly, those who participated in the study are monitored and evaluated through a communication system.

\section{Implementation}

The project used a participatory community approach in developing or enhancing good practices of CBDRRM, focusing on earthquake preparedness. With the participatory community approach, the community will recognize and discover resolutions to their problems, make collective decisions, and make joint planning.

\section{Data Collection Methods}

The data collection methods for this project include primarily TNA with members of the BDRRMO and community leaders. Data from the TNAs were complemented through collection of secondary data and community observations.

Due to the study's reduced preparation time, tools comprising of the TNA guide and community profile worksheet were adopted. The TNA, which was held in Barangay San Jose - Rodriguez, Rizal, highlighted the need to prioritize topics.

To validate the new inferences, the researcher accomplished a feedback session at the end of data collection.

\section{Community Visits}

Initial community visits permitted the researcher to familiarize barangay officers and community members about the project, arrange the project schedule, an informal interview conducted and secondary data gathered such as community profile and CBDRRM plan.

\section{Training Schedule and Participants}

The training required two days to be able to achieve the project objectives.

The invited participants were from Barangay San Jose - Rodriguez, Rizal, consisting of local leaders, officials, staff, and community leaders. Thirty participants consisted of Office of Punong Barangay
(OPB) staff, emergency medical service (EMS), municipal, and barangay disaster risk reduction and management (DRRM) officers.

\section{Resource Person and Specialization}

The resource speaker in Mr. Martin T. Aguda is a safety, emergency management, disaster risk reduction (DRR), and public safety professional. He is an experienced emergency and disaster response operator trained in various lifesaving and rescue disciplines: Emergency Medical Services (EMS), fire protection, collapsed structure search and rescue (CSSR), hazardous materials, anti-terrorism, and incident command system.

\section{Logistical Arrangements}

The preparation for the training took about one month, including preparation of training design, the invitation of the resource speaker, participants, and coordination for the fieldwork.

The earthquake preparedness workshop and training were held at the Conference Room of the Office of Punong Barangay in San Jose, Rodriguez, Rizal.

\section{Organization of Field Work}

The organization of the field day required considerable support from home owners' and community leaders. Hence, appointments with community leaders were fixed well in advance and community members were informed beforehand about the purpose of the lecture participants' visit.

\section{DISCUSSION}

The training and workshop was carried out to capacitate the BDRRMO in conducting earthquake disaster preparedness analysis to improve the CBDRRM systems in the barangay level.

As expected, the expert trainer, Mr. Martin Aguda, shared inputs on CBDRRM and emphasized the need to enhance and improve earthquake disaster preparedness in every community. He also led the participants in identifying the roles and responsibilities of the BDRRMO at the barangay level through workshops. 
Table 1. Summary of training evaluation

Poor Fair Satisfactory $\begin{gathered}\text { Very } \\ \text { Satisfactory }\end{gathered}$ Excellent $\quad$ Average

\section{Content Delivery and Organization}

Pace and structure of the sessions

$\begin{array}{lll}1 & 4 & 25\end{array}$

4.80

Quality of reference materials and handouts

3

Quality of activities and exercises

\section{2}

Clarity of the content and presentations

How would you rate the course overall?

2

3

\section{Facilitator}

The trainer was knowledgeable and well prepared

The trainers were engaging and encouraged questions and participation

The trainers covered all the materials clearly

\section{Facilities}

The location of the training was convenient

The training space was comfortable and conducive to learning

\section{Impact}

Relevance of the topics and presentations for your work

Relevance of the recommendations for your work

Introduction to new approaches and techniques

Strengthening of knowledge about disaster preparedness

Usefulness of the methodology for your work

Usefulness of the experiences and good

practices for your community

\section{Did the training meet your expectations?}

What is the likelihood of using what you learned in this training?

After providing all the necessary inputs, participants were engaged in CBDRRM analysis focusing on earthquake disaster preparedness by giving them situations to analyze through tabletop exercises.

With Mr. Aguda's guidance, participants were engaged in creating emergency contingency planning after an earthquake event where they design. Through this exercise participants were able to generate ideas for earthquake preparedness like provision of information, education, and communication (IEC) materials to all households, assign tricycle and pedicab drivers as the additional ambulatory vehicle during disasters and assign sarisari store owners to become a voluntary source of relief goods after an earthquake event. They were also able to generate recommendations for enhancing and improving the CBDRRM plan of the community.

Table 1 shows the overall rating of the training provided by the 30 participants who filled the evaluation forms. The training was mainly rated as useful to highly useful.

The project was structured to fill the gaps in the earthquake preparedness contingency plan of the barangay. Table 2 shows the expected outcomes for earthquake preparedness based on the National Disaster Risk Reduction and Management Plan (NDRRMP) of the Office of Civil Defense. The measurement of this project's success is based on its 
Table 2. Outcomes of the project based on project objectives

\section{Objectives \\ Output}

Activities

Increased level of

awareness and

enhanced capacity of the

community to threats and

impacts of all hazards

Communities are

equipped with the

necessary skills and capabilities to cope with the impact of disaster

To discuss the roles and responsibilities of the BDRRMO in the whole continuum of earthquake preparedness

To expose participants to field situations where they can apply their learnings from the training hazards leaders workshop

To develop
contingency
emergency plan during
earthquake

earthquake
DRRM is mainstreamed and taken into consideration in the decision

Developed and implemented comprehensive barangay preparedness and response policies, plans, and system including coordination mechanisms and infrastructure
Developed and updated CBDRRM and advocacy

plan and program

- Posting of information, education, and communication (IEC) materials in the community

- Conduct of IEC campaign on geological

Conduct of capacity building activities for BDRRMO and community

Conduct of DRRM and disaster preparedness education and training for the barangay officials

Conduct of contingency planning formulation and

Develop the BDRRM plan

Stock filing and prepositioning of resources

Establishment of one Disaster Operations Center

Enhanced preparedness and response strategies,

Increased coordination through the Incident Command Systems

Better prepared citizenry

Increased coordination, complementation and interoperability of work in CBDRRM

Develop and/or enhanced simulate scenario-based preparedness and response plans with the assistance of MDRRMC

Develop and enhance incident command system coordination and communication system
Key Performance Indicators

800 family

preparedness charts were distributed

1200 earthquake

awareness flyers were

distributed

30 representatives from the Office of Punong Barangay, BDRRMO, MDRRMO, $B F P, P N P$, and AFP attended the training workshop

Conducted contingency planning on November 23, 2019 with 30 attendees

Conducted contingency planning on November 23, 2019 with 30 attendees

MOA with private sector from Phase $1 \mathrm{~K}$ Kasiglahan Village was prepared

Established the Barangay Disaster Operations Center in the Barangay Hall

Scenario-based preparedness plan developed using tabletop exercise during the training workshop

Incident command system communication is already placed

Assigned Pedicab and padyak drivers as additional ambulatory vehicles during disasters

BHWs, EMS, HOA officials were trained last December 13, 2019 
Table 2. Outcomes of the project based on project objectives (continued)

\begin{tabular}{|c|c|c|c|c|}
\hline Objectives & Outcome & Output & Activities & $\begin{array}{l}\text { Key Performance } \\
\text { Indicators }\end{array}$ \\
\hline & $\begin{array}{l}\text { Strengthened } \\
\text { partnership and } \\
\text { coordination } \\
\text { among all key } \\
\text { players and } \\
\text { stakeholders }\end{array}$ & $\begin{array}{l}\text { Partnership arrangements } \\
\text { among stakeholders } \\
\text { established }\end{array}$ & $\begin{array}{l}\text { Update of directory or } \\
\text { database of key players } \\
\text { and stakeholder every } \\
\text { year }\end{array}$ & $\begin{array}{l}\text { Agreed that the } \\
\text { directory will be } \\
\text { updated this } 2020 \\
\text { including HOA }\end{array}$ \\
\hline & & & $\begin{array}{l}\text { Formulate coordination } \\
\text { mechanisms } \\
\text { and guidelines } \\
\text { for partnership } \\
\text { arrangements in the } \\
\text { contingency plan }\end{array}$ & $\begin{array}{l}2 \text { MOAs/ MOUs } \\
\text { formulated ( } 1 \text { sari-sari } \\
\text { store and } 1 \text { toda from } \\
\text { Phase } 1 \mathrm{~K} \text { Kasiglahan) }\end{array}$ \\
\hline
\end{tabular}

BDRRMO - Barangay Disaster Risk Reduction Management Office

MDRRMO - Municipal Disaster Risk Reduction Management Office

BFP - Bureau of Fire Protection

PNP - Philippine National Police

AFP - Armed Forces of the Philippines

MOA - Memorandum of Agreement

BHW - Barangay Health Workers

EMS - Emergency Medical Services

HOA - Homeowners Association

MOU - Memorandum of Understanding

key performance indicator (KPI). KPI measures the value that demonstrates how effectively a project is achieving its key objectives.

The first objective of the project was to generate an understanding of CBDRRM. Through this project, the community became equipped with the necessary skills and capabilities to cope with disaster impacts. Notably, there was an increased level of awareness and enhanced community capacity to the threats and impacts of all hazards.

Besides, the community was equipped with the necessary skills and capabilities to cope with the impact of disasters. The activities involved were developing and updating CBDRRM and advocacy plans and programs, including posting information, education, and communication (IEC) materials to the community and conducting an IEC campaign on geological hazards. Throughout this project, 800 family preparedness charts and 1200 earthquake awareness flyers were distributed to every part of the community.

Discussing the roles and responsibilities of the BDRRMO in the whole continuum of earthquake preparedness was the second objective. With this, DRRM was mainstreamed and taken into consideration in the decision. There were capacity building activities for BDRRMO and community leaders, and DRRM and disaster preparedness education and training were conducted for 30 representatives from the Office of Punong Barangay, BDRRMO, MDRRMO, Bureau of Fire Protection, Philippine National Police, and Armed Forces of the Philippines.

The next step was to expose participants to field situations where they could apply their learning by conducting contingency planning, formulation and workshop, developing the BDRRM plan, stock filing, and prepositioning of resources and establishing a disaster operations center.

Lastly, the project aimed to develop a contingency emergency plan during an earthquake. The activities conducted were a simulation of scenariobased preparedness and response plans with assistance from the Municipal Disaster Risk Reduction Management Council (MDRRMC). There was also enhancement of the incident command system, coordination and communication system, development of guidelines for emergency response protocol in coordination with MDRRMC wherein pedicab and padyak (tricycle) drivers were assigned as additional ambulatory vehicles during disasters, development of conventional and integrated response assessment tools and mechanisms, and formulation of coordination mechanisms and guidelines for partnership arrangements in the contingency plan which included sari-sari stores (convenience stores) and association of tricycle operators and drivers from the community. 


\section{CONCLUSIONS}

"The Big One" might occur with little to no warning. Community preparedness is one way to reduce the vulnerability of the community to an earthquake. Community preparedness will require community members in long-term involvement and a cooperative approach to working with communities to support equal and harmonized development.

With this, the project showed the potential earthquake hazards and dangers that urban poor relocates in Barangay San Jose - Rodriguez, Rizal may face when an earthquake event occurs. The area as a relocation site has an unnecessary risk to the community. This hazard was increased by the disaster-prone design of the relocation homes. The goal of this project was to strengthen local capacity for earthquake emergency preparedness through a CBDRRM approach and to increase the earthquake awareness of the community.

Meanwhile, there is an existing CBDRRM plan for Barangay San Jose that is structured and grounded on a sound legislative framework; however, some challenges still thrive. There is a need for the BDRRMO to get their acts together, enhance their CBDRRM plans and optimize their disaster preparedness. Given that an earthquake may hit the community, the community leaders and community members have no other recourse but to intensify their disaster preparedness, especially on earthquakes.

Furthermore, community members and leaders must increase their capacity to be prepared for disasters by equipping the community with the necessary skills and capabilities to cope with the impacts of disasters, developing and implementing more comprehensive barangay preparedness plans, and strengthening partnerships and coordination among all possible vital players and stakeholders.
Overall, this project was able to achieve the project objectives by attaining all possible KPIs. Sustainability and replicability across all communities and Homeowners Association (HOAs) in the community are suggested in order for Barangay San Jose to be fully prepared and ready for "The Big One".

\section{Disclosure and Conflict of Interest}

I have no conflicts of interest that may inappropriately influence bias in the execution of research and publication of this manuscript.

\section{Acknowledgments}

In full gratitude, I would like to thank the following individuals who supported, assisted, and contributed greatly in carrying out this capstone project. This paper would not have been possible without them:

To Dr. Mary Agnes Santos - Regal, MD, MPH, MSc, my adviser, for constantly guiding and advising me on what to do on every community activity and fieldwork. I thank her for her willingness and dedication to help me by imparting her experiences and ideas which greatly helped in the fulfilment of this capstone project and paper.

To the officials and staff of the Office of Punong Barangay (OPB) San Jose - Rodriguez, Rizal, headed by Hon. Glenn S. Evangelista and the Barangay Disaster Risk Reduction and Management Office of Barangay San Jose headed by Sir Darcy Cruz for extending their help and knowledge beyond their responsibility.

To all community leaders who gave their insights and expertise on the fieldwork which pushed me to improve this project to the best of my abilities. I also extend my outmost gratitude to them for serving as role models of how empowered public health practitioners should be.

Lastly and above all, to God Almighty, for His constant grace and presence, for His love and daily guidance, for the skills and capabilities that $\mathrm{He}$ blessed me with, and for ultimately making all of this possible. 


\section{REFERENCES}

1. UNISDR. Making Development Sustainable: The Future of Disaster Risk Management. Global Assessment Report on Disaster Risk Reduction. Geneva, Switzerland: United Nations Office for Disaster Risk Reduction (UNISDR); 2015.

2. Santos E. Philippines among world's disaster-prone countries. CNN Philippines. 2015 Nov 25 [cited 2019 Dec 16]; Available from: http://cnnphilippines.com/ news/2015/11/25/philippines-fourth-most-disaster-pronecountry.html.

3. UNICEF Philippines. Disaster Risk Reduction. UNICEF Philippines 2014 [cited 2019 Dec 18]; Available from: http://www.unicef.org/philippines/risk_8956.html\#. VFX2sfnF-sO.

4. MMEIRS. Metropolitan Manila Earthquake Impact Reduction Study (MMEIRS). The Republic of the Philippines: Japan International Cooperation Agency (JICA) 2004 Dec [cited 2020 Jan 5]; Available from: https://openjicareport.jica. go.jp/pdf/11788429.pdf.

5. Republic Act No. 10121. Philippine Disaster Risk Reduction and Management Act of 2010. 2019 July 27 [cited 2019 Dec 18]; Available from: http://www.ndrrmc.gov. ph/attachments/article/45/Republic_Act_10121.pdf.

6. van Niekerk D, Coetzee C. African experiences in community-based disaster risk reduction. In: R. Shaw ed. Community-based disaster risk reduction. Bingley, UK: Emerald Publisher; 2012. p.339-49.

7. Izumi T, Shaw R. A new approach of disaster management in Bangladesh: Private sector involvement. risk, hazards \& crisis in public policy, 2014. 5(4):425-45.

8. Kafle S, Murshed Z. Community-based disaster risk management for local authorities: participant's workbook. Pathumthani, Thailand: Asian Disaster Preparedness Center (ADPC); 2006.
9. Shaw R. Role of local actors in community based disaster risk reduction. Ankara, Turkey: Middle-East Technical University Disaster Management Implementation and Research Center; 2009.

10. Surjan A, Redkar S, Shaw R. Community based urban risk reduction: Case of Mumbai. In: R. Shaw, H. Srinivas, A. Sharma eds. Urban risk: An Asian perspective, London: Emerald Publication; 2009.p. 339-54.

(c) (i)(2) Open Access This article is licensed under a BY NC SA Creative Commons Attribution-NonCommercialShareAlike 4.0 International License, which permits use, share - copy and redistribute the material in any medium or format, adapt - remix, transform, and build upon the material, as long as you give appropriate credit, provide a link to the license, and indicate if changes were made. You may do so in any reasonable manner, but not in any way that suggests the licensor endorses you or your use. You may not use the material for commercial purposes. If you remix, transform, or build upon the material, you must distribute your contributions under the same license as the original. You may not apply legal terms or technological measures that legally restrict others from doing anything the license permits. The images or other third party material in this article are included in the article's Creative Commons license, unless indicated otherwise in a credit line to the material. If material is not included in the article's Creative Commons license and your intended use is not permitted by statutory regulation or exceeds the permitted use, you will need to obtain permission directly from the copyright holder. To view a copy of this license, visit https://creativecommons.org/licenses/by-nc-sa/4.0/. 